\title{
Impact of Financial Leverage on Firm Performance
}

\section{Textile Composite Companies of Pakistan}

\author{
Umer Iqbal \\ University of Gujrat \\ Muhammad Usman \\ University of Gujrat
}

\begin{abstract}
The aim of this research is to identify the relationship between financial leverage and the performance of Textile Composite Companies of Pakistan. Pakistan Textile Composite Companies which are listed in PSX (100-index) are selected.5-year data is collected from 2011-2015 and top 16 companies are selected as a sample. Using descriptive statistics, correlation analysis and regression model to identify the results. Results show that financial leverage has negative and significant effect on firm ROE and financial leverage has positive and significant effect on firm ROA. Further study indicates that the high interest rate and more amount of debt decreases the value of equity and has negative impact on firm performance. On the other hand, the amount of debt has positive impact on firm ROA. Results show that financial leverage has positive impact on firm performance if the amount of debts do not exceed from the amount of equity.

Keywords

Financial leverage, Firm performance, ROA, ROE, PSX (100-index)

\section{Introduction}

Financial leverage is very important external financing modes. Financial leverage shows that a business needs finance to purchase a new asset, enhance their production or operational activities, financial leverage is one of the best way for organization to achieve its goal, with the help of the financial leverage a company can not only achieve its goals but also maximize the value of its shareholders. Finance is very important for any business however a business is new and ongoing, financial or non-financial institute need funds to operate its daily activities. In the book of accounting and finance the leverage can be defining as the amount of debts or credit that is uses to purchase of
\end{abstract}


assets, enhance the operational activities or acquiring a new firm. Generally, the cost of borrowed money (leverage) is less than the amount of equity. Using the financial leverage like debts to equity ratio, debts to total assets ratio we can easily identify the financial position of the firm or the amount of leverage that is used in a firm. Financial leverage is very curricular for every business in terms of increase in production level, increase the shareholder value or acquired a new asset. In this research paper we evaluate the impact of financial leverage on the performance of a Textile Companies of Pakistan. Textile Companies is one of the biggest Companies of Pakistan, it contributes $8.5 \%$ in country GDP. Due to the large or biggest sector of Pakistan the Textile Companies are divided into three categories like Composite, Spinning and Weaving. There are many companies which are listed on PSX (100-Index) use the financial leverage in various ways which show different results. It means that if companies use more financial leverage then its result increase the rate of return and rate of risk and vice versa. Discussions, studies and research show that financial leverage and firm performance have negative relationship due to high rate of interest which cause decrease in the profitability of firm. On the other hand, further study show that financial leverage and firm performance have positive relationship because it strong the financial position of company and maximize the value of shares.

\section{Problem statement:}

Does the financial leverage affect to financial performance of Textile composite companies of Pakistan.

Objective of the Research:

The aim of this study is to identify relationship between financial leverage and firm performance of textile composite. This research also tells that how the financial leverage affect to firm performance.

Significance of this Research:

This research is very helpful for researchers and financial managers who deal with different modes of funds and make decisions that includes measuring and evaluating leverage especially when making capital structure decision. Financial leverage can significant affect the value of the firm in positive or negative way.

\section{Literature Review:}

Venture capital and financial leverage are very useful for entrepreneur because entrepreneur have great chance to increase their production or operational activities (Yang Ruili,Xia Kue, 2016). To find out enterprise performance the data is use from china GEM listed companies 2010-2014. The result shows that financial leverage is negatively correlated to firm performance because when companies have more growth opportunities then companies face more conservative financial leverage policy.

High rate of interest and more complicated financial leverage policy have negative impact on the firm overall performance (Astawa Putu,Sudika Putu, 2015). The Government can play a vital role to change the financial leverage policies and solve the financial leverage difficulties by provides low interest rate however, not only all companies take advantage of this facilities but also small and medium business can make growth rapidly. 
The relationship between the financial leverage and performance is negative because as the ratio of debt increases and decrease the performance firm and when the ratio of debt decreases and increase performance of firm (mahira, 2011). This statement shows that performance depends on the ratio of debt.

Financial leverage impact negatively on firm performance and its profitability on the other hand financial leverage cannot impact on the firm size and the firm growth it means that increase in financial leverage decrease in performance and profitability of the firm and decrease in financial leverage increase in performance and profitability of the firm(Rabbani Mahboob,Subhan Iqra, 2015)

There are many factors that effect on firm. profitability financial leverage is one of factor that affect negatively on firm profitability means high rate of leverage decrease firm profitability and low financial increase high profitability of the firms Therefore, right selection of combination of debt and equity is important for managers of any firm is significant negative relationship between the financial leverage and the firm profitability (Ahmed Nawaz,Salman ATIF, 2015). Companies who do not uses borrowed money for its firm purpose it is totally depends on its equity so they are free from any fixed amount and high interest rate which means that there is no financial leverage associated with their companies.

Short-term or long-term loans can decrease the firm overall performance (Awais Mustabsar, Iqbal Wateen, 2016) If the amount of borrowed money is less than the amount of firm total equity it means a company perform bitterly. If the amount of debts is more than the amount of firm total equity the performance of the company is decrease. It is important for financial managers to evaluate the firm total equity value before dealing with leverage.

\section{Methodology}

\section{Unit Analysis}

For this research paper the target Population is all the Pakistan Textile Companies which are listed in PSX (100-index) and 5-year data is taken from 2011-2015. This research paper is useful to understand the impact of financial leverage on the performance of Pakistan Textile Companies listed in PSX (100-index).

\section{Sample Size}

Pakistan Textile Companies is one of the biggest Companies of Pakistan due to this reason it divided into three major categories like Textile Composite, Textile Spinning and Textile Weaving. For this research purpose secondary data is used and we select Textile Composite Company which is listed in PSX (100-Index) and top 16 companies are selected with 5-year data from 2011-2015. With the help of annual reports, we find out the relationship of financial leverage and firm performance. Using EViews.8 all the financial data or information of the firm is calculated.

\section{Variable Description}

After discussion, study or understand the theory of financial leverage we are able to identify the important variables like Debt-Equity ratio, Solvency ratio or Proprietary ratio are independent variable and dependent variables includes return on equity (ROE) and return on assets (ROA). 


\section{Independent Variables}

Debt to Equity Ratio

Debt to equity ratio is very important ratio to measure the financial leverage. This ratio shows that how much companies use debts to operate its financial activates. It also shows the relationship of debts and the value of equity. Debt equity ratio use by (Tugas, 2012), (Opter Tim, 2009) and (Vale, 2011) under their studies.

Solvency Ratio

Solvency ratio is also important indicator to find out the impact of leverage on firm performance. Solvency ratio can be defining as the relationship between total debts and firm total assets. This ratio is used by the (Karamjeet Singh, Firew Chekol Asres, 2010) and (Ucal, Meltem, Oksay Serhan, 2011) under their studies.

Proprietary Ratio

Proprietary ratio is also called equity ratio it can be defining the relationship of shareholder's overall equity and firm total assets. With the help of this ratio we evaluate the impact of leverage on firm performance.

\section{Dependent Variables}

Return on Assets (ROA)

Return on assets is the dependent variable that show the relationship between firm profit and its assts. It shows how much a firm gain profit from its assets. The same measure technique uses by (Richard M. Burton, 2002)(Muammar, 2014) and (Mubin Muhammad, 2014) on their study.

Return on Equity (ROE)

Another dependent variable return on equity that is used to measure profitability it also shows the relationship between net profit and the value of shareholder equity.(William H, Beaver, Stephen G. Ryan, 2012) and(Kabajeh Majid, 2012)show that return on equity is important technique to measure company profitability and same ratio is used in their study.

Table 1- Description of Variables and its measurements

\begin{tabular}{ll}
\hline Variables & Formulas \\
\hline Debt-Equity Ratio & Total debts/Equity \\
\hline Solvency Ratio & Total debts/Total assets \\
\hline Proprietary Ratio & Equity/Total assets \\
\hline Return on Asset & Net profit/Total assets \\
\hline Return on Equity & Net Profit/Equity \\
\hline
\end{tabular}

\section{Hypothesis Testing}

Following hypothesis are developed under this study to find out the effect of Leverage on firm performance

H1: Leverage has positive and significant effect on ROE

H2: Leverage has negative and significant effect on ROE

H3: Leverage has positive and significant effect on ROA

H4: Leverage has negative and significant effect on ROA 
Table 2- Descriptive Statistic

\begin{tabular}{lccccc}
\hline & $\begin{array}{c}\text { DEBT EQUITY } \\
\text { RATIO }\end{array}$ & $\begin{array}{c}\text { PROPRIETORY } \\
\text { RATIO }\end{array}$ & ROA & ROE & $\begin{array}{c}\text { SOLVENCY } \\
\text { RATIO }\end{array}$ \\
\hline Mean & 1.819125 & 0.905975 & 0.173974 & 0.321499 & 0.671600 \\
\hline Median & 0.675000 & 0.550000 & 0.074000 & 0.120000 & 0.410000 \\
\hline Maximum & 13.91000 & 19.27000 & 2.280000 & 5.580000 & 7.230000 \\
\hline Minimum & 0.080000 & 0.010000 & -0.210000 & -0.760000 & 0.053000 \\
\hline Std. Dev. & 2.832431 & 2.364257 & 0.374198 & 0.786685 & 0.960821 \\
\hline Skewness & 2.660285 & 6.313115 & 4.013474 & 4.642001 & 5.205497 \\
\hline Kurtosis & 9.623421 & 47.37586 & 20.25084 & 28.47468 & 33.02719 \\
\hline Jarque-Bera & 240.5939 & 7095.462 & 1206.745 & 2450.506 & 3366.736 \\
\hline Probability & 0.000000 & 0.000000 & 0.000000 & 0.000000 & 0.000000 \\
\hline Sum & 145.5300 & 72.47800 & 13.91790 & 25.71990 & 53.72800 \\
\hline Sum Sq. Dev. & 633.7904 & 441.5872 & 11.06189 & 48.89103 & 72.93091 \\
\hline Observations & 80 & 80 & 80 & 80 & 80
\end{tabular}

Table 3- Correlation Analysis of Variables during the Data of 2011-2015

\begin{tabular}{lcccccc}
\hline & $\begin{array}{c}\text { DEBT } \\
\text { EQUITY } \\
\text { RATIO }\end{array}$ & $\begin{array}{c}\text { PROPRIETORY } \\
\text { RATIO }\end{array}$ & RESID & ROA & ROE & $\begin{array}{c}\text { SOLVENCY } \\
\text { RATIO }\end{array}$ \\
\hline $\begin{array}{l}\text { DEBT } \\
\text { EQUITY } \\
\text { RATIO }\end{array}$ & 1 & -0.162 & -2.724 & 0.261 & 0.470 & -0.003 \\
\hline $\begin{array}{l}\text { PROPRIETORY } \\
\text { RATIO }\end{array}$ & -0.162 & 1 & 5.946 & 0.692 & -0.098 & 0.686 \\
\hline RESID & & & & & & 0.157 \\
\hline ROA & -2.724 & 5.946 & 1 & 0.614 & 0.107 & 0.613 \\
\hline ROE & 0.261 & 0.692 & 0.614 & 1 & 0.172 & -0.030 \\
\hline $\begin{array}{l}\text { SOLVENCY } \\
\text { RATIO }\end{array}$ & 0.470 & -0.098 & 0.107 & 0.172 & 1 & 1 \\
\hline
\end{tabular}

\section{Results and Discussion}

\section{Descriptive Statistics:}

Table 2; show that the mean and standard deviation value of $\mathrm{D} / \mathrm{E}$ ratio is $1.82,2.8$ Proprietary ratio is $0.91,2.3 \mathrm{ROA}$ value is $0.17,0.37 \mathrm{ROE}$ value is $0.32,0.78$ and Solvency ratio value is $0.67,0.96$. This show that the company value of debts is greater than the value of its equity. Proprietary ratio that the company purchase $9 \%$ assets on credit basis, ROA show that companies earn $17 \%$ profits from its total assets, ROE is a profitability ratio that show $32 \%$ shareholder receive from its total profits. Solvency ratio show that company have enough assets to meet its short-term or long-term 
liabilities. Whereas Standard Deviation show that the value of deviation from its mean value.

\section{Correlation Analysis}

Correlation analysis is the analysis that measure the relationship between two variables. The value of correlation is -1 to 1 . If the value is close to 0 it means there is no relationship between variables, if the value is near to 1 or positive it means that one variable is increase the other variable is also increase it has the direct relationship between the variables, if the value is near to -1 or negative it means one variable increase the other variable is decrease it show the inverse relationship between the variables. Using 5\% (0.05) significant level to check the relationship between the variables it is a significant or insignificant.

Table 3: show that $\mathrm{D} / \mathrm{E}$ ratio and ROA have positive or insignificant relationship, D/E have also positive but insignificant relationship with ROE. The relationship of proprietary ratio and ROA positive but insignificant, proprietary ratio or ROE also positive but insignificant, it also shows that solvency ratio and ROA have positive but insignificant, it also shows that Solvency ratio and ROE have positive or significant relationship.

\section{Regression Model}

The first regression model shows the relationship of independent variables with ROE (dependent variable) it show that debt-equity have positive and significant impact on firm performance but Proprietary ratio show that the negative and insignificant impact on firm performance. $\mathrm{H} 1$ is rejected and $\mathrm{H} 2$ is selected it show that financial leverage has negative impact on ROE.

Table 4- Relationship of Independent Variables with ROE (Dependent Variable)

\begin{tabular}{|c|c|c|c|c|}
\hline Dependent Variable: ROE & & & & \\
\hline Method: Least Squares & & & & \\
\hline Date: $02 / 03 / 17$ Time: 17:33 & & & & \\
\hline Sample: 180 & & & & \\
\hline Included observations: 80 & & & & \\
\hline Variable & Coefficient & Std. Error & t-Statistic & Prob. \\
\hline $\mathrm{C}$ & 0.092630 & 0.101428 & 0.913262 & 0.3640 \\
\hline DEBT_EQUITY_RATIO & 0.129531 & 0.028304 & 4.576465 & 0.0000 \\
\hline PROPRIETORY_RATIO & -0.007467 & 0.033909 & -0.220204 & 0.8263 \\
\hline R-squared & 0.221402 & Mean dependent var & & 0.321499 \\
\hline Adjusted R-squared & 0.201179 & S.D. dependent var & & 0.786685 \\
\hline S.E. of regression & 0.703114 & Akaike info criterion & & 2.170184 \\
\hline Sum squared resid & 38.06645 & Schwarz criterion & & 2.259510 \\
\hline Log likelihood & -83.80735 & Hannan-Quinn criter. & & 2.205997 \\
\hline F-statistic & 10.94786 & Durbin-Watson stat & & 1.581905 \\
\hline Prob(F-statistic) & 0.000065 & & & \\
\hline
\end{tabular}


The second regression model show that Debt-Equity ratio and Proprietary ratio both positive or significant impact on firm overall performance. H3 is accepted that show financial leverage have positive impact on ROA.

Table 5- Debt-Equity Ratio and Proprietary Ratio Impact on Firm Performance.

\begin{tabular}{lccrr}
\hline \multicolumn{2}{l}{ Dependent Variable: ROA } \\
\hline Method: Least Squares & & & \\
\hline Date: $02 / 03 / 17 \quad$ Time: $17: 34$ & & & & \\
\hline Sample: 180 & & & & \\
\hline Included observations: 80 & & & & \\
\hline Variable & Coefficient & Std. Error & t-Statistic & Prob. \\
\hline C & -0.026474 & 0.033593 & -0.788076 & 0.4331 \\
\hline DEBT_EQUITY_RATIO & 0.050728 & 0.009374 & 5.411335 & 0.0000 \\
\hline PROPRIETORY_RATIO & 0.119394 & 0.011231 & 10.63106 & 0.0000 \\
\hline R-squared & 0.622509 & Mean dependent var & & 0.173974 \\
\hline Adjusted R-squared & 0.612704 & S.D. dependent var & & 0.374198 \\
\hline S.E. of regression & 0.232875 & Akaike info criterion & & -0.039853 \\
\hline Sum squared resid & 4.175760 & Schwarz criterion & & 0.049473 \\
\hline Log likelihood & 4.594131 & Hannan-Quinn criter. & & -0.004040 \\
\hline F-statistic & 63.48928 & Durbin-Watson stat & & 2.344528 \\
\hline Prob(F-statistic) & 0.000000 & & & \\
\hline
\end{tabular}

\section{Conclusion}

The study of this paper is conducted from Pakistan Textile Composite listed in Pakistan Stock Exchange (100-index) taking 5-year data 2011-2015and with the help of annual reports, we evaluate the firm financial leverage position and the impact of financial leverage on firm overall performance. We applied descriptive analysis, correlation analysis and regression model. The regression model describe that financial leverage have negative or insignificant impact on firm ROE whereas it also describes that financial leverage have positive or significant impact on firm ROA. The results support the hypothesis $\mathrm{H} 2$ and $\mathrm{H} 3$. The results show that increase in financial leverage the value of equity is decrease but the increase in financial leverage the value of assets increase because leverage have negative impact on ROE and positive impact in ROA. Further study or results show that the value of leverage does not exceed the value of equity in this way a leverage have positive impact on firm overall performance.

\section{References}

Ahmed Nawaz,Salman ATIF. (2015). Impact of financial leverage on firm profitability.

Astawa Putu,Sudika Putu. (2015). Intangible capital and leverage to improve financial performance. Social and Behovioral Science, 7.

Awais Mustabsar, Iqbal Wateen. (2016). Impact of Capital Structure on firm Performance. 
Kabajeh Majid, N. F. (2012). The Relationship between the ROA, ROE and ROI Ratios with Jordanian Insurance Public Companies Market Share Prices . International Journal of Humanities and Social Science, 6.

Karamjeet Singh, Firew Chekol Asres. (2010). DETERMINING WORKING CAPITAL SOLVENCY LEVEL AND ITS EFFECT ON PROFITABILITY IN SELECTED INDIAN MANUFACTURING. 14.

mahira, R. (2011). Effect of profitability and financial leverage on capital structure. Economic and Finance, 8.

Muammar, H. M. (2014). Influence Analysis of Return on Assets (ROA), Return on Equity (ROE), Net Profit Margin (NPM), Debt To Equity Ratio (DER), and current ratio (CR), Against Corporate Profit Growth In Automotive In Indonesia Stock Exchange . International Journal of Academic Research in Business and Social Sciences , 14.

Mubin Muhammad, I. A. (2014). Determinant of Return on Assets and Return on Equity and Its Industry Wise Effects: Evidence from KSE (Karachi Stock Exchange). Research Journal of Finance and Accounting , 11.

Opter Tim, H. (2009). The Debt-Equity Choise. Journal of Financial and Quantitative Analysis.

Rabbani Mahboob,Subhan Iqra. (2015). Impact of financial leverage on pakistani firms. Investment and development.

Richard M. Burton, J. L. (2002). Return on Assets Loss from Situational and Contingency Misfits. Management Science, 25.

Tugas, F. C. (2012). A Comparative Analysis of the Financial Ratios of Listed Firms. International Journal of Business and Social Science , 18. 
Ucal, Meltem, Oksay Serhan. (2011). The Solvency Ratio of External Debt (SRED) as an Indicator of Debt Crisis: The Case of Turkey. international journal of economics andd reseach, 7.

Vale, B. (2011). Effects of higher equity ratio on a bank's total funding costs and lending . 17.

William H, Beaver, Stephen G. Ryan. (2012). Biases and Lags in Book Value and Their Effects on the Ability of the Book-to-Market Ratio to Predict Book Return on Equity . journal of Accounting Research, 23.

Yang Ruili,Xia Kue. (2016). Venture capital, financial leverage and enterprise performance. Social and Behavioural Science, 7. 